OPEN ACCESS

Edited by: Stephan Pauleit,

Technical University of

Munich, Germany

Reviewed by:

Leonie K. Fischer,

University of Stuttgart, Germany

Tenley M. Conway,

University of Toronto

Mississauga, Canada

*Correspondence:

Charlie M. Shackleton

c.shackleton@ru.ac.za

Specialty section:

This article was submitted to

Urban Greening,

a section of the journal

Frontiers in Sustainable Cities

Received: 16 May 2021

Accepted: 09 July 2021

Published: 03 August 2021

Citation:

Shackleton CM (2021) Urban Green Infrastructure for Poverty Alleviation: Evidence Synthesis and Conceptual

Considerations.

Front. Sustain. Cities 3:710549 doi: 10.3389/frsc.2021.710549

\section{Urban Green Infrastructure for Poverty Alleviation: Evidence Synthesis and Conceptual Considerations}

\author{
Charlie M. Shackleton* \\ Department of Environmental Science, Rhodes University, Makhanda, South Africa
}

The multiple benefits of urban green infrastructure (UGI) that support sustainable cities are increasingly acknowledged, and yet the bulk of research over the past decade or so has focused on only a small subset of the numerous benefits, notably recreation, physical and mental health, and regulating services. In contrast, there is very little information on the contribution of UGI to several of the other Sustainable Development Goals (SDGs), and in particular SDG 1 of reducing poverty, despite the pervasiveness of poverty globally. This paper considers the diverse direct and indirect ways in which UGI can contribute to poverty alleviation, drawing on the limited evidence from various regions of the world. The direct links between UGI and poverty alleviation is via three means, namely provision of (1) consumptive or provisioning goods such as wild foods and firewood, (2) employment in UGI development, maintenance, and restoration, and (3) land for urban agriculture, income generation and dwelling. There are also a number of indirect links such as cash savings, improved physical and mental health, improved social networks, improved educational outcomes, and regulation of potential natural disasters. However, the commonly unequal distribution of UGI within and between cities means that the poverty alleviation potential and benefits are inequitably distributed, often against those who are most in need of them, i.e., the urban poor. This demands greater attention to promoting the equitable distribution and quality of UGI and mainstreaming of UGI into poverty reduction strategies and programmes and vice versa, as well as greater examination of the links between UGI and poverty alleviation in a greater range of contexts.

Keywords: employment, non-timber forest products, poverty alleviation, provisioning services, urban green infrastructure

\section{INTRODUCTION}

Sustainable development has been a globally accepted goal by international, national, and subnational agencies for over two decades. This was concretised by over $95 \%$ of the world's nations adopting an ambitious set of development targets, known as the Millennium Development Goals (MDGs) in 2000. Those targets were monitored nationally and globally over a 15-year period. That experience set the foundation for a more consultative and inclusive process to design and agree the subsequent Sustainable Development Goals (SDGs) for the following 15 years, namely 
2015-2030 (United Nations, 2015). The 17 SDGs span all areas of sustainable development, ranging from poverty and inequality to food, health, justice, and climate change (United Nations, 2015). Each SDG has been further subdivided and translated into a series of 169 integrated targets that are monitored at national and global levels via 232 different indicators (Le Blanc, 2015; Hák et al., 2016).

Whilst achievement of all the SDGs is important for progressing towards sustainability, the growing proportion of humans living in urban areas requires that SDG 11, namely "to make cities inclusive, safe, resilient, and sustainable" needs increasing attention. When signed in 2015, the world's urban population was $\sim 3.97$ billion ( $54 \%$ of the world population), and only 5 years later it was 4.4 billion, and will be $\sim 5$ billion ( $58 \%$ ) by the end of the 15 year SDG period in 2030 (Angel et al., 2011), representing a $26 \%$ increase in just 15 years. It is further projected that $\sim 68 \%$ of all humans will live in urban areas by 2050 (Angel et al., 2011). In other words, the future of humanity is undoubtedly an urban one. Consequently, decisions, and investments made now pertaining to urban design, functionality, quality and livability, and ultimately sustainability, will shape the lived reality and quality of life of urban generations to come. Doing so will also contribute to other SDGs. For example, Gómez Martína et al. (2020) demonstrate how restoration of the Ladegaardsaa River in Copenhagen (Denmark) contributes to at least 10 of the SDGs, including poverty reduction through green employment, and Turner-Skoff and Cavender (2019) argue that planting trees in urban areas can contribute to 15 of the 17 SDGs to some extent.

The planning, provision, maintenance, conservation, and restoration of Urban Green Infrastructure (UGI) is increasingly acknowledged as a vital constituent of any holistic and realistic strategies towards urban sustainability (Breuste et al., 2015; Sharifi, 2021) and the SDGs generally (Gómez Martína et al., 2020). As the multifunctional, interconnected network of natural and human-made green and blue spaces, corridors, and elements (Kambites and Owen, 2006; Pauleit et al., 2011), UGI provides an array of ecosystem services (and disservices) that contribute to multiple facets of human wellbeing. Despite the wide diversity of ecosystem services provided by UGI, the bulk of research over the past decade or so has focused on only a small subset of the numerous benefits, notably recreation, physical and mental health, and regulating services (Kabisch et al., 2015). In contrast, there is only limited information on the contribution of UGI to several of the other SDGs, and of specific interest in this paper, SDG 1, which is "to end poverty in all its forms everywhere." This is likely to be because the majority of research on urban ecology generally, and UGI and urban ecosystem services specifically, has been conducted in Global North countries (Kabisch et al., 2015; Nagendra et al., 2018; Shackleton et al., 2021), where poverty is not as pressing an issue as it is in many Global South regions. This demands that Global South researchers take a lead in this regard (Nagendra et al., 2018).

The intention of SDG 1 of ending poverty in all its forms is both ambitious and complex, and further confounded by the use of multiple definitions of poverty (Mabughi and Selim, 2006), which make verification complicated. For example, the first target under SDG 1 is to eradicate extreme poverty (my emphasis), which was defined in income terms of living on less than US\$1.25 per day in 2015 (United Nations, 2015) (currently US\$1.90). Thus, in this target there is no consideration of other forms of poverty relating to basic needs such as food poverty, energy poverty, the lack of dignity or voice, and so on. The second target to "half the number of people living in poverty in all its dimensions according to national definitions" (my emphasis), acknowledges the complexity but leaves it up to national governments to define poverty and consequently how to measure and monitor it. Most often this is done in cash income terms (Barrett, 2005), thereby elevating economics above other facets of sustainable development. This is because of the relative ease of definition, measurement, monitoring and universal understanding of income poverty at a variety of scales and across "wealth" groups (Angelsen and Wunder, 2003).

However, there are cogent arguments for more inclusive definitions of poverty beyond income and asset poverty (Mabughi and Selim, 2006), which are increasingly synonymous with the concept of wellbeing. For example, the World Bank (2001) defines poverty as "a pronounced deprivation of wellbeing related to lack of material income or consumption, low levels of education and health, vulnerability and exposure to risk, no opportunity to be heard, and powerlessness." Thus, in this article, poverty is considered as a bundle of human wellbeing facets relating to income, dignity, belonging, freedom to make decisions, choice, and participation (in civil, social, economic and cultural activities, and decisions).

When considering the links between UGI and poverty alleviation, it is necessary to differentiate between poverty mitigation and poverty reduction, collectively deemed as poverty alleviation (Angelsen and Wunder, 2003; FAO, 2003). The former relates to strategies and actions that prevent a decline into deeper poverty. The latter constitutes initiatives and practises that result in a lasting improvement in circumstances, asset base and wellbeing. It is also necessary to recognise that poverty is not static, but that poverty rates and ratios vary in time and space in response to national- and international-scale drivers (e.g., economic performance, wars, or epidemics), as well as dynamics at more local and even household scale (e.g., illness, loss or gain of a job). Whilst focus should be on the most poor, there is often a sector of any community that moves in and out of poverty (i.e., above or below a particular poverty line measure) as circumstances change, i.e., the transient poor (Ward, 2016).

Within this context, the objectives of this paper are to (i) assess the state of knowledge on the links between UGI and poverty alleviation, (ii) consider the conceptual links between UGI and urban poverty alleviation, and (iii) prompt future research into this relationship.

\section{A RESEARCH LACUNA ON THE LINKS BETWEEN UGI AND POVERTY ALLEVIATION}

Although research on the links between ecosystem services generally and poverty alleviation has taken off in the last 5 years 
(Wang et al., 2021), an examination of the literature indicates relatively little research on the links between UGI specifically (or urban greening) and poverty alleviation. In mid-February 2021 I conducted a literature search using Scopus and the Web of Science using the following search string "urban green *" OR "green infrastructure" AND "poverty *". This returned 79 unique papers across the two databases. Of these, 10 were inaccessible to me due to being in pay journals or not in English. The abstracts, objectives and methods of the remaining 69 papers were scanned and 57 discarded, mostly because either (i) they did not focus on poverty alleviation, but simply used the word "poverty" to describe the broad context of the study setting, or a cohort of respondents, or (ii) links to poverty alleviation benefits were expressed, but not actually studied. That left 12 papers, to which I added five from my own knowledge, resulting in 17 (Table 1) that I read the entire paper once or more times. Of the 17 papers, 12 were from the USA and South Africa (six apiece), two from Bangladesh, and one each from Mozambique, Spain and Africa (multiple countries covered). There is clearly a need for a significantly greater global coverage. Whilst these sources were informative in shaping concepts of the links between UGI and poverty alleviation, the final number was too small to undertake any systematic review of the themes, trends and conclusions. Nevertheless, this summary of the number of papers itself reveals the research lacuna in this domain and thereby points to the need for more concerted research in this regard.

\section{CONCEPTUALISING THE LINKS}

Based on the 17 studies and my own experiences it was possible to identify and conceptualise a number of direct and indirect links between the provision and maintenance of UGI and the potential for poverty alleviation (Figure 1). However, the extent to which UGI does, or might, contribute to poverty alleviation in a particular setting will depend upon the extent of UGI, its functional and compositional quality, its physical, and regulatory accessibility (especially to those most in need), the extent of poverty and the prevalence and effectiveness of other antipoverty measures. The direct links are those through which the poverty alleviation effects (however small or large) are manifest via immediate and useful resources such as food, timber, medicines, shelter, and income. As indicated in Figure 1, they encompass (i) provisioning or consumptive goods (such as food, medicines and construction timber), (ii) formal and informal employment to provide and maintain UGI, and (iii) space for a number of livelihood activities and benefits. The indirect means are where UGI provides longer-term investments in or insurance to human wellbeing, and hence ability to escape poverty or be less vulnerable to it through better health, social connections, and safety. Making the relationship work requires embedding poverty alleviation in the various strategies to promote UGI, and on the other hand promoting the provision of UGI as a part of poverty alleviation strategies (Dunn, 2010). Given that poverty is most pervasive in Global South contexts, recognising and acting on this relationship would be most apposite there, and can bolster and complement existing arguments and motivations for the provision and maintenance of UGI.

\section{THE CURRENT EVIDENCE BASE}

Following Figure 1, I briefly consider the evidence base demonstrating the direct links between UGI and the potential for poverty alleviation. Here I focus on the direct links due to both space limitations for this article, and because some of the indirect links, such as with health and education benefits have been comparatively well researched (e.g., Lee and Maheswaran, 2011; Van den Berg et al., 2015; Li and Sullivan, 2016; Kuo et al., 2018).

\section{Provisioning Services From UGI}

There is much literature on the collection of an extensive array of different products from green spaces and elements in urban settings around the world (Shackleton et al., 2017; Synk et al., 2017; Tiwary et al., 2020; Shackleton, 2021). This includes products such as water, firewood, wild foods (e.g., wild fruits, vegetables, herbs, fungi, insects, fish, honey), medicinal plants, plant parts and fibres for crafts and decorative and utilitarian items, and timber for construction. For example, Schlesinger et al. (2015) inventoried the use of use of nine different biological products (i.e., excluding water) or non-timber forest products (NTFPs) in six cities in five sub-Saharan African countries, and found that $74 \%$ of urban households collected at least one NTFP locally. In northern Botswana, Joos-Vandewalle et al. (2018) found that $80 \%$ or more of the urban households used locally sourced firewood, wild fruits, vegetables, fish, reeds for mats, grass for brushes, and waterlilies for food. In Dhaka (Bangladesh), Uddin (2006) reported that $60 \%$ of poor people in the city were totally reliant on locally sourced leaves and firewood for cooking energy, and that the majority of houses in the slums were made of forest and agricultural materials harvested from urban and peri-urban forests and fields. Collection or foraging for such products has been well examined in poorer and Global South contexts, but nevertheless, it is also prevalent in Global North towns and cities too. For example, Kangas and Markkanen (2001) reported that $68 \%$ of the urban households of Joensuu (Finland) had collected wild berries in the survey period, with a similar figure of 54\% in Poland (Golos and Kaliszewski, 2016). In a large survey of over 17,000 mostly urban households across 28 European countries, Lovrić et al. (2020) found that 28\% had collected one or more NTFPs in the previous 12 months from their local environment or further afield. This is similar to the USA, where Short Gianotti and Hurley (2016) reported that $27 \%$ of urban households in central and eastern Massachusetts personally collected wild plants or fungi, and Robbins et al. (2008) revealed that 22\% of urban respondents in New England had collected plant NTFPs from urban and rural settings in the preceding 5 years.

Whilst the collection of wild products is well known, relatively little urban research has made the explicit links between the availability and use of such products to household welfare and the role in poverty alleviation (Uddin, 2006; Shackleton et al., 2018). This in contrast to rural research with dozens of papers per year 
TABLE 1 | Seventeen studies considering one or more links between urban greening/infrastructure and poverty alleviation, arranged in chronological order (see section on "Research lacuna" for method).

\begin{tabular}{|c|c|c|c|}
\hline No. & References & Country & Pertinent focus area \\
\hline 1 & Kuo (2001) & USA & Effects of UGI on coping with life by inner city poor \\
\hline 2 & Uddin (2006) & Bangladesh & Direct and indirect links of urban trees on poverty alleviation \\
\hline 3 & Falxa-Raymond et al. (2013) & USA & UGI restoration jobs training as pathways out of poverty for low-skilled workers \\
\hline 4 & Kaoma and Shackleton (2014) & South Africa & Collection and use of tree products from UGI as a means of mitigating poverty \\
\hline 5 & Kaoma and Shackleton (2015) & South Africa & $\begin{array}{l}\text { Estimation of cash and non-cash income from tree products from UGI and how it } \\
\text { effects poverty status }\end{array}$ \\
\hline 6 & Shamasunder et al. (2015) & USA & Benefits accruing from a poverty alleviation home-gardening project \\
\hline 7 & Cumming et al. (2017) & South Africa & $\begin{array}{l}\text { Commentary on use of ecological infrastructure to attain the SDGs, including poverty } \\
\text { alleviation }\end{array}$ \\
\hline 8 & Segui et al. (2017) & Spain & Benefits from urban allotments, including poverty mitigation \\
\hline 9 & Burdine and Taylor (2018) & USA & Urban food gardens, volunteering and benefits, contrasting poor and less poor areas \\
\hline 10 & Cilliers et al. (2018) & South Africa & Review of urban food gardens in alleviating poverty \\
\hline 11 & Douglas (2018) & Africa & $\begin{array}{l}\text { Poverty as a driver of encroachment on UGI, and thereby increasing vulnerability to } \\
\text { ecosystem disservices }\end{array}$ \\
\hline 12 & Quinn et al. (2018) & Mozambique & Ecosystem adaptation to climate change to simultaneously address poverty \\
\hline 13 & Shackleton et al. (2018) & South Africa & $\begin{array}{l}\text { Commentary and synthesis of studies from South Africa on importance of UGI, } \\
\text { including for poverty alleviation }\end{array}$ \\
\hline 14 & Tallis et al. (2018) & USA & $\begin{array}{l}\text { Assessment of the relative magnitude of effects of UGI or poverty status on school } \\
\text { achievement scores and hence intergenerational poverty }\end{array}$ \\
\hline 15 & Birtchnell et al. (2019) & Bangladesh & $\begin{array}{l}\text { Different forms of UGI in helping slum dwellers adapt and reduce their vulnerability to } \\
\text { a range of social and environmental challenges }\end{array}$ \\
\hline 16 & Browning and Rigolon (2019) & USA & $\begin{array}{l}\text { Analysis of UGl levels during childhood to underpin long-term benefits in terms of } \\
\text { income later in life and hence poverty alleviation }\end{array}$ \\
\hline 17 & King and Shackleton (2020) & South Africa & Quantification of income in formal and informal sectors from maintenance of UGl \\
\hline
\end{tabular}

examining poverty dynamics in relation to provisioning services and NTFP use (e.g., Leßmeister et al., 2018; Pullanikkatkil and Shackleton, 2018; Hoang et al., 2020; Walle and Nayak, 2020). In urban contexts, ecological studies (e.g., Hurley and Emery, 2018) focus primarily on the species available and quantities harvested, possibly along with the potential ecological impacts. Social studies on the other hand, mostly consider who harvests, their motivations for doing so, and knowledge levels and transfer (e.g., Synk et al., 2017; Garekae and Shackleton, 2020). Some consider urban markets and the potential supply and demand dynamics, or the policy and urban planning, and management implications (e.g., McLain et al., 2014).

With respect to the contribution of such harvesting to household income (cash and non-cash), there are relatively few studies. Kaoma and Shackleton (2015) quantified the value of only tree products harvested by urban households in three towns in northern South Africa, and reported that they provided an average of $20 \%$ of total household income, and more than $30 \%$ for the poorest households (it would be much higher if non-tree products had been included too). Additionally, they found that inclusion of the value of harvested tree products in household income estimates reduced the proportion of households living below the poverty line by $5-10 \%$ per town. Expressed as the inverse, if there was not any UGI in these towns, a further $5-10 \%$ of households would be struggling below the poverty line. This echoed the findings of Davenport et al. (2012), also in South Africa, in valuing NTFPs collected from peri-urban commonages by urban residents in three small towns, that without local NTFPs 11-13\% more households would fall below the poverty line. Lannas and Turpie (2009) quantified the value of provisioning services (mostly grazing, firewood, wild vegetables, and medicines) from Mfuleni wetland in Cape Town at US $\$ 2,003$ per user household per year, which was well above the national poverty line. These estimates do not include the poverty mitigation dimensions, in which many urban households' use of urban NTFPs helps ease their poverty but not sufficiently to move them above the poverty line. Fo example, the qualitative study of Birtchnell et al. (2019) considers the innovative and intimate care and management of individual trees and containers to supply medicinal and culinary herbs, foods and firewood to slum dwellers in Dhaka (Bangladesh).

The significance of urban NTFPs from UGI is further emphasised during times of hardship and shocks. These may be at the level of the household (such as retrenchment, illness or death of the primary breadwinner, or loss or significant damage to property through fire or floods), or to entire neighbourhoods and communities through natural disasters (such as floods, earthquakes, tornados), large price increases in basic foodstuffs, or civil strife, and armed conflict. During such times many households turn to natural capital found in UGI to cope until they are able to re-establish themselves. In the absence of wild products from UGI many would not be able to cope, and so would have a greater likelihood of falling into poverty, or intensification of existing poverty. Thus, provisioning products 


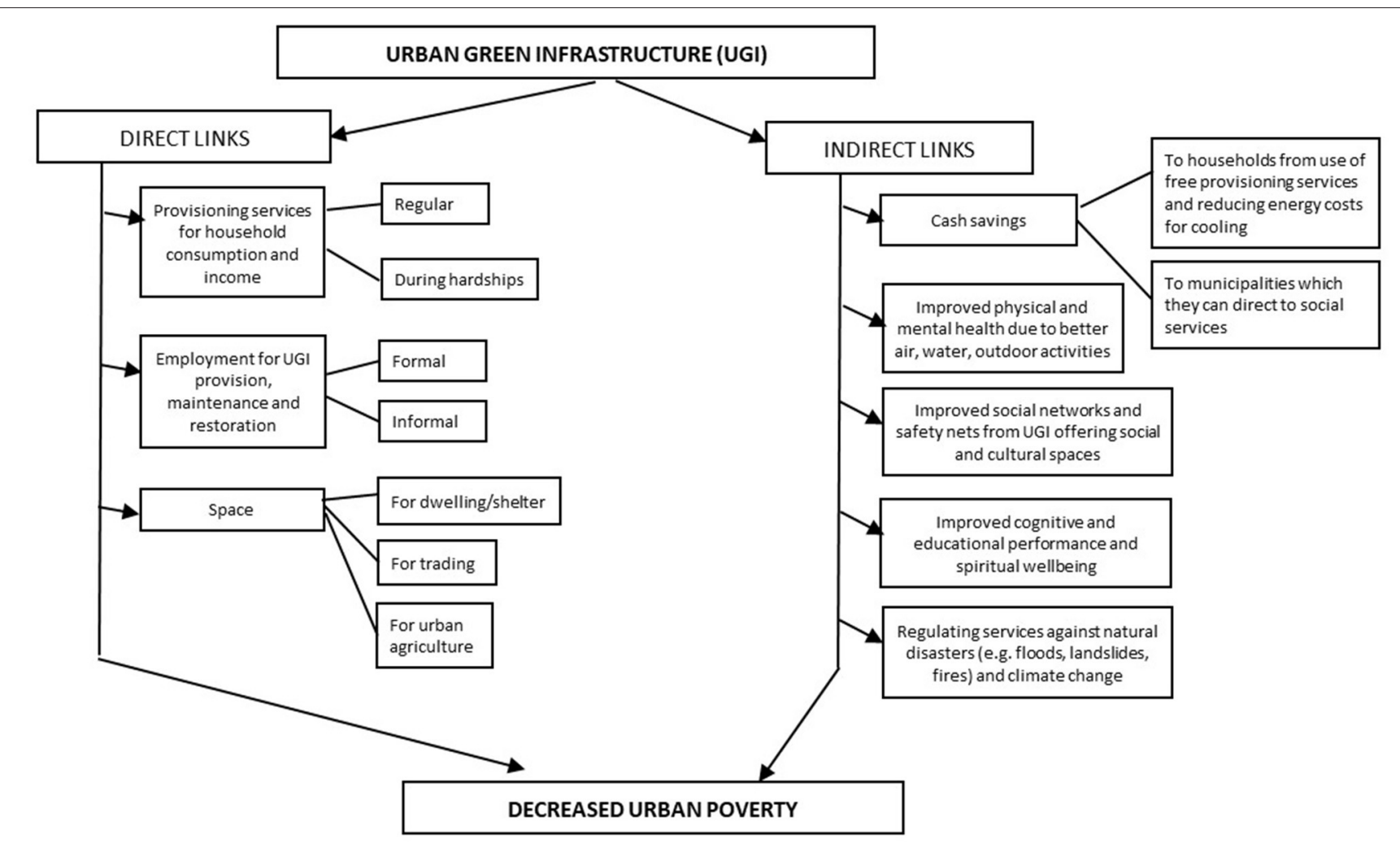

FIGURE 1 | The direct and indirect links through which urban green infrastructure can contribute to the alleviation of urban poverty.

from UGI act as a safety net or buffer against poverty in times of distress. This is illustrated by Dalu and Shackleton's (2018) investigation of the coping responses of urban dwellers of informal housing zones in three coastal towns to a major flooding event resulting from above-normal rainfall. Locally collected resources (timber for building and fencing, and thatch for roofing) provided the equivalent of $57 \%$ of the costs of repairing or rebuilding the damaged structures, ranging from a mean of 46 to $70 \%$ in the three towns. In another example, a survey of 420 NTFP traders (of which $65 \%$ were in urban settings) in five southern African countries, Weyer et al. (2018) found that almost one-third had started trading in NTFPs because of death or illness of the main income earner in the household, starkly illustrating the importance of UGI as a safety-net in times of need. A particular harsh example is the increased reliance on wild foods during armed conflicts, such as the siege of Sarajevo in Bosnia (Redžić, 2010).

The findings of Weyer et al. (2018) also illustrate that the value of provisioning services from UGI in mitigating or reducing poverty is not solely via household use, but also through cash generation from trade in NTFPs in their raw or processed forms. There are markets for various NTFPs such as medicinal plants, wild foods, crafts, and household utensils in many cities of the world for those knowing where to look. However, the source of the goods on sale is unlikely to be solely from UGI, but may also be brought in from neighbouring rural regions. Yet there is undoubtedly use of UGI to collect NTFPs for income generation as reported, for example, by Grabbattin et al. (2011) in the USA and Kaoma and Shackleton (2015) in South Africa. The levels of income earned specifically from urban sourced NTFPs are unknown and hence the real or potential contribution to poverty alleviation is solely conjecture at this time.

\section{Employment in UGI Provision, Maintenance, and Restoration}

Most formal green spaces on public and private lands in towns and cities require human capital to manage and maintain them. This may also apply to some informal green spaces too. The employment creation potential of UGI is rarely mentioned as a benefit of UGI in academic literature detailing or listing the contributions or values of UGI, or urban forestry, to urban sustainability and human wellbeing (King and Shackleton, 2020). This is because it is either taken for granted, or because the employment of skilled and unskilled workers to develop and maintain (or restore) UGI is regarded as a financial cost to city budgets. Hence, the growing number of cost-benefit analyses demonstrating that in most settings the benefits outweigh the costs. However, King and Shackleton (2020) argued that in settings of high unemployment, typical of many Global South regions, that hiring of workers to maintain or restore UGI could be viewed as an investment against poverty and in skills development and work experience. Indeed, they found that the "green collar" sector of developing and maintaining public and 
private UGI accounted for 3-5\% of all employment per town across 12 towns in the Eastern Cape province of South Africa. The number of green collar employees was positively related to town size and relative development or affluence. Indeed, Shackleton and Blair (2013) found that amongst respondents to a survey on the benefits of public green spaces, approximately one-third of poor households mentioned employment creation as a benefit, compared to $<3 \%$ of affluent households doing so. The majority of the jobs are unskilled, which means low barriers to entry to some of the poorest citizens and hence an attractive poverty alleviation opportunity. The preponderance of low-skilled jobs in the sector was also noted in the USA by Pinderhughes (2007).

The direct poverty alleviation contribution of green collar employment will depend upon the nature of the jobs and their respective wage levels. In economically strong contexts and in countries with strong labour and minimum wage regulations, most or all such jobs are likely to pay above the poverty line, including for unskilled jobs (Pisani and Yoshkowitz, 2005; Pinderhughes, 2007). This is not necessarily so in poorer countries or cities. In South Africa, those employed in the public sector are protected by minimum wage regulations, however, due to excessive unemployment nationally and many unskilled workers, those working in the informal sector may not enjoy adequate wage levels or job security. Across the 12 towns surveyed by King and Shackleton (2020), approximately twothirds of the jobs were in the informal sector, mostly as gardeners employed to maintain private gardens at homes of more affluent residents, with most earning at or below the national minimum wage (King and Shackleton, 2021). However, there may be noncash remuneration benefits for some household gardeners, such as food and accommodation, as reported from case studies in Ghana (Awumbila et al., 2017) and Brazil (Chase, 2008). King and Shackleton (2021) estimated that there are likely to be between 700,000 and 1 million such gardeners in South Africa (with a population of $\sim 66$ million people), making it one of the largest employment sectors nationally. In Dhaka (Bangladesh), Uddin (2006) states that there are thousands of people involved in roadside nurseries, mostly owned and run by people with no, or limited, education and formal skills, but generally earning an income above the poverty line, and with the larger ones employing several other people in their business.

The focus on employment is because it provides a vehicle for income generation through engagement with UGI (Dunn, 2010). However, Browning and Rigolon (2019) show that the positive indirect effects of neighbourhood greenness during childhood, even in poorer neighbourhoods, can translate into higher incomes later in life and hence reduce intergenerational poverty. This is because of the indirect effects of exposure to and experience of UGI as a child of improving potential academic achievement, creativity and emotional intelligence, all of which are important in gaining employment and performance later in life (Browning and Rigolon, 2019). This echoes the benefits of "green collar" employment, where jobs defined by working with or in nature are frequently valued beyond just the income earned, but also the psychological and health benefits of being in nature (Falxa-Raymond et al., 2013). This resonates with the seminal work of Kuo (2001) who revealed that those living in greener environments, even in poor neighbourhoods, felt that they were better able to identify and deal with major issues affecting them and thereby regarded such issues as less severe and less persistent.

\section{Space}

By its very definition UGI occupies space within and adjacent to the urban matrix, and such space may be sequestered for a variety of purposes that may contribute to poverty alleviation, including urban agriculture, food stalls, informal trading or even space for people to live. The use of UGI for such purposes is typically driven by a combination of rapid rates of urban population growth in many regions and low formal employment opportunities, meaning that the space that UGI occupies offers opportunities to contribute to livelihood needs, such as shelter, food and income generation. This is particularly so for the urban poor, although there is much literature reporting on unauthorised encroachment on UGI by economic and political elites (e.g., Mensah et al., 2018), but which cannot be viewed through a poverty alleviation lens.

Urban agriculture can be found in one form or another in every city of the world. It may be practised in public and private spaces. The motivations to engage in urban agriculture are diverse (Hamilton et al., 2014; Di Fiore et al., 2021), including for health, food security, recreation, cultural, and income reasons. But in poor regions and for poor households, there is little doubt about its value to household food security and for some, income, i.e., very basic needs at the heart of poverty alleviation (Simiyu and Foeken, 2014; Pribadi and Pauleit, 2016). The extent to which urban agriculture can alleviate poverty within a household or community is debated (Hamilton et al., 2014; Cilliers et al., 2018). However, both sides of the debate generally fail to acknowledge the extent of poverty alleviation from urban agriculture is generally context specific, based on factors such as size of land available, its productivity, access to and affordability of inputs (e.g., water, fertiliser), tenure security and so on. Thus, for some, urban agriculture is a side activity that offers recreation and some fresh food adding to dietary diversity; yet for others it is a core survival strategy without which the household would be in dire difficulties, and others still it provides both fresh food and some level of income (Cilliers et al., 2018). Availability of land is important for urban agriculture, and can often be a scarce commodity in densely populated areas. But many poor communities find novel ways to mitigate this, such as through vertical and rooftop gardens, container planting indoors, and next to the dwelling, and growing trees in relatively small spaces. All of these contribute to household needs, as illustrated by Birtchnell et al. (2019) in the slums of Dhaka (Bangladesh), Roy et al. (2018) in Dar es Salaam (Tanzania), and Gopal and Nagendra (2014) in the slums of Bangalore (India). The poverty mitigation or alleviation "value" of gardens extend beyond the physical bounds of the garden, with Voicu and Been (2008) reporting that property values in New York (USA) were enhanced if adjacent to a community garden, which in turn resulted in higher taxes payable to the city authority which could, in theory, be invested in social services to the poor. Community gardens may also provide some employment (e.g., Burdine and Taylor, 2018). As with green employment, 
engagement in gardening is also usually associated with a number of positive outcomes unassociated with remuneration, in terms of better motivation, stress reduction, social connections and physical health (e.g., Shamasunder et al., 2015).

Equally important for some, is the use of UGI as a space to earn an income through various means, such as selling goods to pedestrians, repair services for electronic or mechanical goods, small-scale plant nurseries, or photographers snapping people in public parks. Using tree-lined streets or the edges of formal and informal green spaces to offer such services is a common sight in many burgeoning cities such as Dhaka (Uddin, 2006), Mumbai (Salès, 2018), and Ibadan (Adebayo and Akinyemi, 2019), whereas in others, urban authorities seek to limit them to certain places, or even ban them (e.g., Kazembe et al., 2018). Being able to occupy attractive places or ones sheltered from the elements by trees, especially in hot tropical climates, close to busy streets and pavements at little or no cost is a vital livelihood opportunity for many, especially the poor (Uddin, 2006; Nagendra and Gopal, 2010). Informal plant nurseries along roadsides are worth mentioning because they are common in many countries of the Global South, they make use of the space and shelter afforded by roadside UGI, but they also contribute to its reproduction by propagating and selling a diversity of plant species to passers-by. Mean incomes are also usually well above the poverty line. For example, in Ethiopia, Molla et al. (2020) calculated net incomes as US\$14,628 per nursery per annum, whilst in Kenya, Rutto and Odhiambo (2017) recorded incomes of $\sim$ US $\$ 9,474$ per nursery per annum.

A significant expression of the "occupation" of UGI space for livelihood needs is that of using it for temporary or permanent dwellings (e.g., Chitonge and Mfune, 2015; Mensah et al., 2018). With rapid urban growth in most Global South towns and cities, many new migrants find themselves living in slums or informal housing areas (Douglas, 2018), which may be for only a short period, but for some it may extend for years or decades. Undeveloped land, typically UGI, is therefore an attractive space for construction of a dwelling (Uddin, 2006), or a place to find shelter and provisioning goods in the face of homelessness (Koprowska et al., 2020). If in large numbers or high densities, such use will transform the inherent nature of UGI, diminishing its accessibility to others and its ability to offer a full range of ecosystem services. But at lower densities, then certain elements of the original UGI might be maintained or enriched. For example, Kaoma and Shackleton (2014) found that in three towns in South Africa, homesteads of informal dwellings had a higher density of trees than formal neighbourhoods with long-established or new housing.

\section{CONCLUSION}

Poverty is a pervasive global issue, most pressing in the Global South, but not restricted to it. Urban sustainability is also a pressing issue, and yet the two are not sufficiently envisaged together, debated in the same fora, or combined in a given development strategy for win-win outcomes in both domains. In this paper I iterate the thesis mooted by Uddin (2006) and Dunn
(2010) that there are clear links between them. Consequently, investments in UGI are likely to have clear benefits in reducing or mitigating urban poverty, especially of the most poor. This needs to be added to the calls and motivations for increased budgets for urban greening. Indeed, it is a critical time for this relationship to be acknowledged and acted upon because both UGI and poverty are under threat from multiple and overlapping dynamics, such as climate change, covid-19 and erosion of UGI in many Global South cities as they expand and develop.

Unfortunately, it is not as simple as just advocating for more UGI, because in many towns and cities there is insufficient UGI to meet many of the other functions it performs. In these contexts, there is need for a transformation of mindsets and frameworks of planners and decision-makers, towards the mainstreaming of UGI and nature-based solutions in all planning and management domains, not just relegated to the parks department. In other settings there is extensive UGI in public spaces, but it is inequitably distributed (Nesbitt et al., 2019; Venter et al., 2020), meaning that the benefits are not accessible to all, and often those in most need have the least availability or access to UGI. This inequity has implications beyond just recreation and health aspects highlighted in the literature (e.g., Jennings et al., 2016, 2017), but includes material wellbeing and poverty as highlighted here. The issue of inequitable distributions of quantity and quality of UGI intersects with notions of "Rights to the City" (Harvey, 2003; Friendly, 2013; Purcell, 2014) and the social values ascribed by different stakeholders to UGI. It also concerns the range of choices and freedoms around the uses to which UGI can be put and the consequent benefit flows. This reinforces that investment in UGI can also be considered as an investment in poverty alleviation via employment and other direct and indirect links and should be considered in poverty alleviation discourses, policies and programmes, and vice versa. Indeed, Birtchnell et al. (2019) urge for a reframing of urban greening discourses and framings in the Global South, to better resonate with the realities of poverty and informality that characterise most Global South towns and cities.

Any integration of poverty issues into UGI plans and programmes, and vice versa, must also be sensitive to the reality that UGI can also generate ecosystem disservices (Lyytimäki and Sipilä, 2009; Von Döhren and Haase, 2015). This is particularly pertinent because the poor are often disproportionately exposed to ecosystem disservices such as floods, wind damage, mudslides and exposure to harmful diseases and animals when collecting water or provisioning goods. Coupled with a lower asset base and response capacity means that the effects of some ecosystem disservices can be particularly devastating (Douglas, 2018; Davoren and Shackleton, 2021). Thus, the nature and location of the UGI needs to be carefully planned and managed to reduce rather than exacerbate poverty levels.

Although the case has been made in this paper about the clear and intuitive direct links between UGI and poverty alleviation, the evidence is still very limited, and much of it has not been framed within a poverty alleviation lens. Additionally, the evidence comes from only a handful of countries, currently mostly South Africa and the USA. Consequently, there is a clear need for more research and advocacy into the relationship 
and from a wider diversity of contexts to augment and advance arguments for UGI, especially in poor communities and countries, which can underpin significant improvements in livelihoods and wellbeing. To this end I would suggest the need for more context specific studies, i.e., grounded, qualitative, quantitative and interdisciplinary research that also involves nonresearch stakeholders into the relationship between UGI and poverty alleviation. In the Global South there is more widespread multifunctional poverty including basic needs, coupled with an often higher vulnerability to shocks due to lower household asset bases and weaker institutional safety-nets. Thus, the potential poverty alleviation potential via UGI is likely to span the full range of direct and indirect pathways as indicated in Figure 1. However, the wider and more pervasive poverty in the Global South demands that researching and securing the direct pathways is likely to address this more pressing need. In the Global North, where basic needs are met to a far greater extent, and where there are more widespread institutional safety-nets for the poor, the research and advocacy focus should be more, albeit not exclusively, on the indirect links whilst being explicit on the poverty alleviation dimensions or potential.

Given that opportunities for poverty alleviation through UGI are context specific, one must be cautious about generalising research needs and questions. However, I see some pressing questions that can transcend or explicitly address context specificities. The first is to consider what types of UGI best benefit the poor in specific contexts? This is necessary to inform city planners and parks agencies around the types of spaces and, species and products that will best support the urban poor in their needs for food, income, and space. The second question relates to how to ensure the equitable distribution of UGI so that the urban poor have proximate and ready access and can use

\section{REFERENCES}

Adebayo, K., and Akinyemi, A. (2019). 'Wheelbarrow livelihoods', urban space and antinomies of survival in Ibadan, south west Nigeria. Intn. Dev. Plann. Rev. 41, 23-42. doi: 10.3828/idpr.2018.22

Angel, S., Parent, J., Civco, D. L., Blei, A., and Potere, D. (2011). The dimensions of global urban expansion: estimates and projections for all countries, 2000-2050. Progr. Plann. 75, 53-107. doi: 10.1016/j.progress.2011.04.001

Angelsen, A., and Wunder, S. (2003). "Exploring the forest-poverty link: key concepts, issues and research implications," in CIFOR Occasional Paper 40, (Bogor: CIFOR), 70.

Awumbila, M., Teye, J. K., and Yaro, J. A. (2017). Of silent maids, skilled gardeners and careful madams: gendered dynamics and strategies of migrant domestic workers in Accra, Ghana. GeoJournal 82, 957-970. doi: 10.1007/s10708-016-9711-5

Barrett, C. B. (2005). Rural poverty dynamics: development policy implications. Agric. Econ. 32, 45-60. doi: 10.1111/j.0169-5150.2004.00013.x

Birtchnell, T., Gill, N., and Sultana, R. (2019). Sleeper cells for urban green infrastructure: harnessing latent competence in greening Dhaka's slums. Urb. For. Urb. Green. 40, 93-104. doi: 10.1016/j.ufug.2018.05.014

Breuste, J., Artmann, M., Li, J., and Xie, M. (2015). Special issue on green infrastructure for urban sustainability. J. Urb. Plann. Dev. 14:A2015001. doi: 10.1061/(ASCE)UP.1943-5444.0000291

Browning, M. H., and Rigolon, A. (2019). Could nature help children rise out of poverty? Green space and future earnings from a cohort in ten US cities. Environ. Res. 176:108449. doi: 10.1016/j.envres.2019.04.016 the UGI for purposes that best suit them. Third, what barriers hinder use of UGI for direct poverty alleviation? Such barriers might include design or formal regulatory barriers, as well as informal barriers to access some UGI or the norms of what is "allowed" (or not) in specific spaces. For example, some city authorities disallow picking of fruits or trading of goods in public parks. Other parks might charge access fees which limit the ability of poorer citizens to access them. In whose interests were such regulations developed and why, and what might be the result of relaxing them? Fourth, how can city authorities better design and manage UGI towards greater poverty alleviation? This requires integrating a poverty alleviation lens when planning for UGI, as well as involving the urban poor to understand what best suits their needs. However, material poverty often overlaps with perceived powerlessness and lack of voice. Thus, innovative, sensitive and respectful approaches will be required to hear the voices of the poor and engender their participation. Fifth, as empirical studies and evidence accumulates, would be a metaanalysis, or comparative case examples, of how does it vary between and within countries and contexts?

\section{AUTHOR CONTRIBUTIONS}

The author confirms being the sole contributor of this work and has approved it for publication.

\section{ACKNOWLEDGMENTS}

This work was funded by the South African Research Chairs Initiative of the Department of Science and Innovation and the National Research Foundation of South Africa (Grant no. 84379).

Burdine, J. D., and Taylor, D. E. (2018). Neighbourhood characteristics and urban gardens in the Toledo metropolitan area: staffing and voluntarism, food production, infrastructure, and sustainability practices. Local Environ. 23, 198-219. doi: 10.1080/13549839.2017.1397614

Chase, J. (2008). Their space: security and service workers in a Brazilian gated community. The Geogr. Rev. 98, 476-495. doi: 10.1111/j.1931-0846.2008.tb00313.x

Chitonge, H., and Mfune, O. (2015). The urban land question in Africa: the case of urban land conflicts in the City of Lusaka, 100 years after its founding. Habitat Intn. 48, 209-218. doi: 10.1016/j.habitatint.2015.03.012

Cilliers, S. S., Siebert, S. J., du Toit, M. J., Barthel, S., Mishra, S., Cornelius, S. F., et al. (2018). Garden ecosystem services of sub-Saharan Africa and the role of health clinic gardens as social -ecological systems. Landsc. Urb. Plann. 180, 294-307. doi: 10.1016/j.landurbplan.2017.01.011

Cumming, T. L., Shackleton, R. T., Forster, J., Dini, J. Khan, A., Gumula, M., et al. (2017). Achieving the national development agenda and the Sustainable Development Goals (SDGs) through investment in ecological infrastructure: a case study of South Africa. Ecosys. Serv. 27, 253-260. doi: 10.1016/j.ecoser.2017.05.005

Dalu, M. T., and Shackleton, C. M. (2018). The potential use of natural resources in urban informal settlements as substitutes for financial capital during flooding emergencies. Phy. Chem. Earth 104, 18-27. doi: 10.1016/j.pce.2018.03.002

Davenport, N. A., Shackleton, C. M., and Gambiza, J. (2012). The direct use value of municipal commonage goods and services to urban households in the Eastern Cape, South Africa. Land Use Pol. 29, 548-557. doi: 10.1016/j.landusepol.2011.09.008 
Davoren, E., and Shackleton, C. M. (2021). "Ecosystem disservices in Global South cities," in Urban Ecology in the Global South, eds C. M. Shackleton, S. S. Cilliers, E. Davoren, and M. du Toit (New York, NY: Springer), 265-292.

Di Fiore, G., Specht, K., and Zanasi, C. (2021). Assessing motivations and perceptions of stakeholders in urban agriculture: a review and analytical framework. Intn. J. Urb. Sustain. Dev. 13:3798. doi: $10.1080 / 19463138.2021 .1904247$

Douglas, I. (2018). The challenge of urban poverty for the use of green infrastructure on floodplains and wetlands to reduce flood impacts in intertropical Africa. Landsc. Urb. Plann. 180, 262-272. doi: 10.1016/j.landurbplan.2016.09.025

Dunn, A. D. (2010). Siting green infrastructure: legal and policy solutions to alleviate urban poverty and promote healthy communities. Boston Coll. Enviro. Aff. Law Rev. 37, 41-66.

Falxa-Raymond, N., Svendsen, E., and Campbell, L. K. (2013). From job training to green jobs: a case study of a young adult employment program centred on environmental restoration in New York City, USA. Urb. For. Urb. Green. 12, 287-295. doi: 10.1016/j.ufug.2013.04.003

FAO (2003). State of the World's Forests 2003: Part II. Selected Current Issues in the Forest Sector. Rome: Food and Agricultural Organisation (FAO).

Friendly, A. (2013). The right to the city: theory and practice in Brazil. Plann. Theory Pract. 14, 158-179. doi: 10.1080/14649357.2013.783098

Garekae, H., and Shackleton, C. M. (2020). Urban foraging of wild plants in two medium-sized South African towns: people, perceptions, and practices. Urb. For. Urb. Green. 49:126581. doi: 10.1016/j.ufug.2020.126581

Golos, P., and Kaliszewski, A. (2016). Economic importance of selected non-wood forest products in Poland. Sylwan 160, 336-343.

Gómez Martína, E., Giordano, R., Pagano, A., van der Keur, P., and Máñez Costa, M. (2020). Using a system thinking approach to assess the contribution of nature based solutions to sustainable development goals. Sci. Total Environ. 738:139693. doi: $10.1016 /$ j.scitotenv.2020.139693

Gopal, D., and Nagendra, H. (2014). Vegetation in Bangalore's slums: boosting livelihoods, wellbeing and social capital. Sustain 6, 2459-2473. doi: $10.3390 /$ su6052459

Grabbattin, B., Hurley, P. T., and Halfacre, A. (2011). I still have the old tradition: the co-production of sweetgrass basketry and coastal development. Geoforum 42, 638-649. doi: 10.1016/j.geoforum.2011.06.007

Hák, T., Janoušková, S., and Moldan, B. (2016). Sustainable development goals: a need for relevant indicators. Ecol. Indic. 60, 565-573. doi: 10.1016/j.ecolind.2015.08.003

Hamilton, A. J., Bury, K., Mok, H. F., Barker, S. F., Grove, J. R., and Williamson, V. G. (2014). Give peas a chance? Urban agriculture in developing countries-a review. Agron. Sustain. Dev. 34, 45-73. doi: 10.1007/s13593-013-0155-8

Harvey, D. (2003). The right to the city. Intn. J. Urb. Region. Res. 27, 939-941. doi: $10.1111 / \mathrm{j} .0309-1317.2003 .00492 . \mathrm{x}$

Hoang, C. V., Tran, T. Q., Nguyen, Y. H., and Nguyen, L. T. (2020). Forest resources and household welfare: empirical evidence from North Central Vietnam. Nat. Res. Forum 44, 311-333. doi: 10.1111/1477-8947. 12206

Hurley, P. T., and Emery, M. R. (2018). Local provisioning ecosystem services in urban forests: forageable woody species in New York City, USA. Landsc. Urb. Plann. 170, 266-275. doi: 10.1016/j.landurbplan.2017. 09.025

Jennings, V., Floyd, M. F., Shanahan, D., Coutts, C., and Sinykin, A. (2017). Emerging issues in urban ecology: implications for research, social justice, human health, and well-being. Popul. Environ. 39, 69-86. doi: 10.1007/s11111-017-0276-0

Jennings, V., Larson, L., and Yun, J. (2016). Advancing sustainability through urban green space: cultural ecosystem services, equity, and social determinants of health. Intn. J. Environ. Res. Public Heal. 13:196. doi: 10.3390/ijerph1302 0196

Joos-Vandewalle, S., Wynberg, R., and Alexander, K. A. (2018). Dependencies on natural resources in transitioning urban centers of northern Botswana. Ecosys. Serv. 30, 342-349. doi: 10.1016/j.ecoser.2018.02.007

Kabisch, N., Qureshi, S., and Haase, D. (2015). Human-environment interactions in urban green spaces: a systematic review of contemporary issues and prospects for future research. Environ. Impact Assess. Rev. 50, 25-34 doi: 10.1016/j.eiar.2014.08.007
Kambites, C., and Owen, S. (2006). Renewed prospects for green infrastructure planning in the UK. Plann. Pract. Res. 21, 483-496. doi: 10.1080/02697450601173413

Kangas, K., and Markkanen, P. (2001). Factors affecting participation in wild berry picking by rural and urban dwellers. Silva Fennica 35, 487-495. doi: $10.14214 /$ sf.582

Kaoma, H., and Shackleton, C. M. (2014). Homestead greening is widespread amongst the urban poor in three medium-sized South African towns. Urb. Ecosys. 17, 1191-1207. doi: 10.1007/s11252-014-0362-3

Kaoma, H., and Shackleton, C. M. (2015). The direct use value of urban tree non-timber forest products to household income in poorer suburbs in South African towns. For. Pol. Econ. 61, 104-112. doi: 10.1016/j.forpol.2015. 08.005

Kazembe, L. N., Nickanor, N., and Crush, J. (2018). Informalised containment: food markets and the governance of the informal food sector in Windhoek, Namibia. Environ. Urban. 32, 461-480. doi: 10.1177/09562478198 67091

King, A., and Shackleton, C. M. (2020). Maintenance of private and public urban green space provides significant employment in Eastern Cape towns, South Africa. Urb. For. Urb. Green. 54:126740. doi: 10.1016/j.ufug.2020. 126740

King, A., and Shackleton, C. M. (2021). Working in poverty: informal employment of household gardeners in Eastern Cape towns, South Africa. Dev. South. Afr. 1-14. doi: 10.1080/0376835X.2021.1940867

Koprowska, K., Kronenberg, J., Kuzma, I. B., and Łaszkiewicz, E. (2020). Condemned to green? Accessibility and attractiveness of urban green spaces to people experiencing homelessness. Geoforum 113, 1-13. doi: 10.1016/j.geoforum.2020.04.017

Kuo, F. E. (2001). Coping with poverty: impacts of environment and attention in the inner city. Environ. Behav. 33, 5-34. doi: 10.1177/00139160121972846

Kuo, M., Browning, M. H., Sachdeva, S., Lee, K., and Westphal, H. (2018). Might school performance grow on trees? examining the link between greenness and academic achievement in urban high-poverty schools. Front. Psych. 9:1669. doi: 10.3389/fpsyg.2018.01669

Lannas, K. S., and Turpie, J. K. (2009). Valuing the Provisioning services of wetlands: contrasting a rural wetland in Lesotho with a peri-urban wetland in South Africa. Ecol. Soc. 14:18. doi: 10.5751/ES-02919-140218

Le Blanc, D. (2015). Towards integration at last? the sustainable development goals as a network of targets. Sustain. Dev. 23, 176-187. doi: 10.1002/sd.1582

Lee, A. C., and Maheswaran, R. (2011). The health benefits of urban green spaces: a review of the evidence. J. Public Health 33, 212-222. doi: 10.1093/pubmed/fdq068

Leßmeister, A., Heubach, K., Lykke, A. M., Thiombiano, A., Wittig, R., and Hahn, K. (2018). The contribution of non-timber forest products (NTFPs) to rural household revenues in two villages in south-eastern Burkina Faso. Agrofor. Sys. 92, 139-155. doi: 10.1007/s10457-016-0021-1

Li, D., and Sullivan, W. C. (2016). Impact of views to school landscapes on recovery from stress and mental fatigue. Landsc. Urb. Plan. 148, 149-158. doi: 10.1016/j.landurbplan.2015.12.015

Lovrić, M., Da Re, R., Vidale, E., Prokofieva, I., Wong, J., Pettenella, D., et al. (2020). Non-wood forest products in Europe: a quantitative overview. For. Pol. Econ. 116:102175. doi: 10.1016/j.forpol.2020.102175

Lyytimäki, J., and Sipilä, M. (2009). Hopping on one leg-The challenge of ecosystem disservices for urban green management. Urb. For. Urb. Green. 8, 309-315. doi: 10.1016/j.ufug.2009.09.003

Mabughi, N., and Selim, T. (2006). Poverty as social deprivation: a survey. Rev. Soci. Econ. 62, 181-204. doi: 10.1080/00346760600721122

McLain, R. J., Hurley, P. T., Emery, M. R., and Poe, M. R. (2014). Gathering "wild" food in the city: rethinking the role of foraging in urban ecosystem planning and management. Local Environ. 19, 220-240. doi: $10.1080 / 13549839.2013 .841659$

Mensah, C. A., Gough, K. V., and Simon, D. (2018). Urban green spaces in growing oil cities: the case of Sekondi-Takoradi Metropolis, Ghana. Intn. Dev. Plann. Rev. 40, 371-395. doi: 10.3828/idpr.2018.16

Molla, M., Abtew, A. A., and Tebkew, M. (2020). Socioeconomic contributions of small-scale private urban tree nurseries in Gondar and Bahirdar Cities. Cogent Food Agric. 6:1785104. doi: 10.1080/23311932.2020. 1785104 
Nagendra, H., Bai, X., Brondizio, E. S., and Lwasa, S. (2018). The urban south and the predicament of global sustainability. Nat. Sustain. 1, 341-349. doi: 10.1038/s41893-018-0101-5

Nagendra, H., and Gopal, D. (2010). Street trees in Banglaore: density, diversity, composition, and distribution. Urb For. Urb. Green. 9, 129-137. doi: 10.1016/j.ufug.2009.12.005

Nesbitt, L., Meitner, M. J., Girling, C., Sheppard, S. R., and Lu, Y. (2019). Who has access to urban vegetation? A spatial analysis of distributional green equity in 10 US cities. Landsc. Urb. Plann. 181, 51-79. doi: 10.1016/j.landurbplan.2018.08.007

Pauleit, S., Liu, L., Ahern, J., and Kazmierczak, A. (2011). "Multifunctional green infrastructure planning to promote ecological services in the city," in Urban Ecology: Patterns, Processes and Applications, eds J. Niemelä, J. H. Breuste, T. Elmqvist, G. Guntenspergen, P. James, and N. E. McIntyre (Oxford: Oxford University Press), 271-285.

Pinderhughes, R. (2007). Green-Collar Jobs: An Analysis of the Capacity of Green Businesses to Provide High Quality Jobs for Men and Women With Barriers to Employment. Berkeley, CA: Office of Energy and Sustainable Development. Available online at: https://community-wealth.org/sites/clone. community-wealth.org/files/downloads/report-pinderhughes.pdf

Pisani, M. J., and Yoshkowitz, D. W. (2005). Grass, sweat and sun: an exploratory study of the labour market for gardeners in South Texas. Soc. Sci. Quart. 86, 229-251. doi: 10.1111/j.0038-4941.2005.00300.x

Pribadi, D. O., and Pauleit, S. (2016). Peri-urban agriculture in Jabodetabek Metropolitan Area and its relationship with the urban socioeconomic system. Land Use Pol. 55, 265-274. doi: 10.1016/j.landusepol.2016. 04.008

Pullanikkatkil, D., and Shackleton, C. M. (2018). Poverty Reduction Through Non-Timber Forest Products: Personal Stories. Springer Nature.

Purcell, M. (2014). Possible worlds: Henri Lefebvre and the right to the city. J. Urb. Aff. 36, 141-154. doi: 10.1111/juaf.12034

Quinn, C. F., Hoard, J. F., Chen, C., Coffee, J. E., Quintela, C. E., Parker, B. A., et al. (2018). Adaptation and poverty reduction in Mozambique: an opportunity for developing countries to lead. Clim. Pol. 18, 146-150. doi: 10.1080/14693062.2016.1258631

Redžić, S. (2010). Use of wild and semi-wild edible plants in nutrition and survival of people in 1430 days of siege of Sarajevo during the war in Bosnia and Herzegovina (1992-1995). Collegium Anthrop. 34, 551-570.

Robbins, P., Emery, M., and Rice, J. L. (2008). Gathering in Thoreau's backyard" nontimber forest product harvesting as a practice. Area 40, 265-277. doi: 10.1111/j.1475-4762.2008.00794.x

Roy, M., Shemdoe, R., Hulme, D., Mwageni, M., and Gough, A. (2018). Climate change and declining levels of green structures: life in informal settlements of Dar es Salaam, Tanzania. Landsc. Urb. Plann. 180, 282-293. doi: 10.1016/j.landurbplan.2017.11.011

Rutto, G. C., and Odhiambo, K. O. (2017). Socio-economic importance of tree nurseries in Eldoret municipality, Uasin Gishu County (Kenya). Afr. Enviro. Rev. J. 2, 146-154.

Salès, L. (2018). The street vendors act and the right to public space in Mumbai. Articulo J. Urb. Res. 17:3631. doi: 10.4000/articulo.3631

Schlesinger, J., Drescher, A., and Shackleton, C. M. (2015). Socio-spatial dynamics in the use of wild natural resources: evidence from six rapidly growing medium-sized cities in Africa. Appl. Geogr. 56, 107-115. doi: 10.1016/j.apgeog.2014.11.013

Segui, A. E., Mackiewicz, B., and Rosol, M. (2017). From leisure to necessity: urban allotments in alicante Province, Spain in times of crisis. ACME 16, 276-304.

Shackleton, C. M. (2021). "Provisioning services in Global South cities," in Urban ecology in the Global South, eds C. M. Shackleton, S. S. Cilliers, E. Davoren, and M. du Toit (Cham: Springer), 203-226.

Shackleton, C. M., and Blair, A. (2013). Perceptions and use of public green space is influenced by its relative abundance in two small towns in South Africa. Landsc. Urb. Plann. 113, 104-112. doi: 10.1016/j.landurbplan.2013. 01.011

Shackleton, C. M., Blair, A., De Lacy, P., Kaoma, H., Mugwagwa, N., Dalu, M. T., et al. (2018). How important is green infrastructure in small and mediumsized towns? Lessons from South Africa. Landsc. Urb. Plann. 80, 273-281. doi: 10.1016/j.landurbplan.2016.12.007
Shackleton, C. M., Cilliers, S. S., Davoren, E., and du Toit, M. (2021). "The need for an urban ecology of the Global South," in Urban ecology in the Global South, eds C. M. Shackleton, S. S. Cilliers, E. Davoren, and M .du Toit (Cham: Springer), 1-26.

Shackleton, C. M., Hurley, P. T., Dahlberg, A., Emery, M. R., and Nagendra, H. (2017). Urban foraging: a ubiquitous human practice but overlooked by urban planners, policy and research. Sustain 9:1884. doi: 10.3390/ su9101884

Shamasunder, B., Mason, R., Ippoliti, L., and Robledo, L. (2015). Growing together: poverty alleviation, community building and environmental justice through home gardens in Pacoima, Los Angeles. Environ. Just. 8, 72-77. doi: 10.1089/env.2015.0005

Sharifi, A. (2021). Urban sustainability assessment: an overview and bibliometric analysis. Ecol. Indic. 121:107102. doi: 10.1016/j.ecolind.2020. 107102

Short Gianotti, A. G., and Hurley, P. (2016). Gathering plants and fungi along the urban-rural gradient: uncovering differences in the attitudes and practices among urban, suburban and rural landowners. Land Use Pol. 57, 555-563. doi: 10.1016/j.landusepol.2016.06.019

Simiyu, R. R., and Foeken, D. W. (2014). Urban crop production and poverty alleviation in Eldoret, Kenya: Implications for policy and gender planning. Urb. Stud. 51, 2613-2628. doi: 10.1177/0042098013506046

Synk, C. M., Kim, B. F., Davis, C. A., Harding, J., Rogers, V., Hurley, P. T., et al. (2017). Gathering Baltimore's bounty: characterizing behaviours, motivations and barriers of foragers in an urban ecosystem. Urb. For. Urb. Green. 28, 97-102. doi: 10.1016/j.ufug.2017.10.007

Tallis, H., Bratman, G. N., Samhouri, J. F., and Fargione, J. (2018). Are California elementary school test scores more strongly associated with urban trees than poverty? Front. Psychol. 9:2074. doi: 10.3389/fpsyg.2018. 02074

Tiwary, A., Vilhar, U., Zhiyanski, M., Stojanofski, V., and Dinca, L. (2020). Management of nature-based goods and services provisioning from the urban common: a pan-European perspective. Urb. Ecosys. 23, 645-657. doi: 10.1007/s11252-020-00951-1

Turner-Skoff, J. B., and Cavender, N. (2019). The benefits of trees for liveable and sustainable communities. Plants People Planet 1, 323-335. doi: 10.1002/ ppp3.39

Uddin, M. N. (2006). The relationship between urban forestry and poverty alleviation: Dhaka as a case study (Unpubl. thesis), Swedish University of Agricultural Sciences, Alnarp.

United Nations (2015). Transforming Our World: The 2030 Agenda for Sustainable Development. New York, NY: United Nations.

Van den Berg, M., Wendel-Vos, W., van Poppel, M., Kemper, H., van Mechelen, W., and Maas,. J. (2015). Health benefits of green spaces in the living environment: a systematic review of epidemiological studies. Urb. For. Urb. Green. 14, 806-816. doi: 10.1016/j.ufug.2015.07.008

Venter, Z. S., Shackleton, C. M., van Staden, F., Selomane, O., and Masterson, V. A. (2020). Green Apartheid: urban green space remains unequally distributed across income and race geographies in South Africa. Landsc. Urb. Plann. 203:103889. doi: 10.1016/j.landurbplan.2020.103889

Voicu, I., and Been, V. (2008). The effect of community gardens on neighboring property values. Real Estate Econ. 36, 241-283. doi: 10.1111/j.1540-6229.2008.00213.x

Von Döhren, P., and Haase, D. (2015). Ecosystem disservices research: a review of the state of the art with a focus on cities. Ecol. Indic. 52, 490-497. doi: 10.1016/j.ecolind.2014.12.027

Walle, Y., and Nayak, D. (2020). Analysing Households' dependency on non-timber forest products, poverty alleviation potential, and socioeconomic drivers: evidence from Metema and Quara Districts in the dry forests of Amhara Region, Ethiopia. J. Sustain. For. 23:22. doi: 10.1080/10549811.2020.1867185

Wang, B., Zhang, Q., and Cui, F. (2021). Scientific research on ecosystem services and human well-being: a bibliometric analysis. Ecol. Indic. 125:107449. doi: 10.1016/j.ecolind.2021.107449

Ward, P. S. (2016). Transient poverty, poverty dynamics and vulnerability to poverty: an empirical analysis using a balanced panel from rural China. World Dev. 78, 541-553. doi: 10.1016/j.worlddev.2015.10.022 
Weyer, D., Shackleton, C. M., and Adam, Y. O. (2018). HIV/AIDS and other household shocks as catalysts of local commercialisation of non-timber forest products. Dev. Pol. Rev. 36, O285-O301. doi: 10.1111/dpr.12261

World Bank (2001). Poverty and Inequality Analysis. New York, NY: World Bank.

Author Disclaimer: Any opinion, finding, conclusion or recommendation expressed in this material is that of the author and the NRF does not accept any liability in this regard.

Conflict of Interest: The author declares that the research was conducted in the absence of any commercial or financial relationships that could be construed as a potential conflict of interest.
Publisher's Note: All claims expressed in this article are solely those of the authors and do not necessarily represent those of their affiliated organizations, or those of the publisher, the editors and the reviewers. Any product that may be evaluated in this article, or claim that may be made by its manufacturer, is not guaranteed or endorsed by the publisher.

Copyright (c) 2021 Shackleton. This is an open-access article distributed under the terms of the Creative Commons Attribution License (CC BY). The use, distribution or reproduction in other forums is permitted, provided the original author(s) and the copyright owner(s) are credited and that the original publication in this journal is cited, in accordance with accepted academic practice. No use, distribution or reproduction is permitted which does not comply with these terms. 